\title{
Seroprevalence of Toxoplasma gondii and Neospora caninum in Small Ruminants in Luxor, Egypt
}

\section{Shireen S. Aboelwafa ${ }^{1}$, Alsagher O. Ali ${ }^{2}$, Rania Hamada ${ }^{3}$, Hassan Y.A.H. Mahmoud ${ }^{2 *}$}

${ }^{1}$ Veterinarian in the Directorate of Veterinary Medicine, Luxor, Egypt; ${ }^{2}$ Division of Infectious Diseases, Animal Medicine Department, Faculty of Veterinary Medicine, South Valley University, Qena 83523, Egypt; ${ }^{3}$ Division of clinical pathology, pathology and clinical pathology Department, Faculty of Veterinary Medicine, Damanhour University, El-Beheira 22511, Egypt.

\begin{abstract}
Toxoplasma gondii and Neospora caninum are intracellular protozoan parasites that are distributed worldwide and of major economic importance in the livestock industry especially sheep and goats. Sheep and goats are thought to be biological indicators of environmental contamination with $T$. gondii and $N$. caninum oocysts. In addition, in developing countries such as Egypt, where sheep and goat meat is commonly consumed, T. gondii and N. caninum infection in small ruminants may also affect public health risks. So that we estimate the prevalence of $T$. gondii and $N$. caninum infections in Egyptian small ruminants, by using enzyme-linked immunosorbent assay (ELISA) to assess the seroprevalence in 92 sheep and 92 goats from four districts in Luxor governorate (Al-Qurnah, Armant, At-Tod, Esna). A total of 92 sheep were sampled, of which 37 (40.2\%) were positive for $T$. gondii, six (6.5\%) were positive for $N$. caninum and four (4.3\%) were positive for both. Out of 92 tested goats 32 (34.8\%) were positive for T. gondii. However, $N$. caninum was not recorded in examined goats. The highest infection rate of T. gondii for sheep and goats were in Esna (46.7\%) and Armant (37.0\%) respectively, while the highest result of $N$. caninum antibody for sheep were at Al-Qurnah (9.4\%). Our study also recorded $62.5 \%$ from the aborted ewes and $62.8 \%$ from the aborted does were seropositive for anti- T. gondii antibody. Moreover, the result of anti- $N$. caninum antibody in aborted ewes was 8.3\%. Significant differences ( $\mathrm{p}$ value $<0.0001$ ) were observed among previously aborted females when evaluated as risk factors for $T$. gondii infection in both ewes and does. Overall, our study was considered as an initial survey on toxoplasmosis and neosporosis in Luxor governorate also the results of this study showed a broad distribution for both protozoa in evaluated sheep and goat flocks.
\end{abstract}

Keywords | Protozoan, Parasites, Sheep, Goats, Egypt, ELISA

Received | September 06, 2021; Accepted | December 04, 2021; Published | January 10, 2022

*Correspondence | Hassan Y.A.H. Mahmoud, Division of Infectious Diseases, Animal Medicine Department, Faculty of Veterinary Medicine, South Valley University, Qena 83523, Egypt; Email: mhassan@vet.svu.edu.eg

Citation | Aboelwafa SS, Ali AO, Hamada R, Mahmoud HYAH (2022). Seroprevalence of Toxoplasma gondii and Neospora caninum in small ruminants in Luxor, Egypt. Adv. Anim. Vet. Sci. 10(2): 412-420.

DOI | http://dx.doi.org/10.17582/journal.aavs/2022/10.2.412.420

ISSN (Online) | 2307-8316

\section{INTRODUCTION}

T oxoplasmosis and neosporosis are protozoan diseases that are distributed globally and responsible for great economic losses in farm animals (Sánchez-Sánchez et al., 2018). Toxoplasmosis is a cosmopolitan zoonotic disease caused by a protozoan parasite, Toxoplasma gondii ( $T$. gondii) and it is of great concern for both animals and public health (Hill et al., 2005). The protozoan parasite Neospora caninum ( $N$. caninum) is a Toxoplasma-like organism and the causative agent of neosporosis in animals. Subsequently, $T$. gondii and $N$. caninum are closely related apicomplexan parasites, sharing many morphological and biological features, (Sánchez-Sánchez et al., 2018) and are associated with reproductive problems in livestock (De Barros et al., 2020). 
Domestic cats and other felids are definitive hosts of $T$. gondii, a large variety of mammals and birds that serve as intermediate hosts (Dubey, 1996). Sheep and goats are considered the highest susceptible herbivorous animals for infections with T. gondii (Stelzer et al., 2019) causing significant reproductive disorders such as embryonic death and resorption, fetal death and mummification, abortion, stillbirth, and weakness in newborn animals (Dubey, 2009; Hill et al., 2005). Dogs act as definitive hosts for N. caninum. That protozoan is a major pathogen for neosporosis in cattle and it occasionally causes clinical infections in horses, goats, sheep, and deer (Dubey, 2003). Although neosporosis is a major cause of abortion in cattle worldwide (Dubey et al., 2007) abortion and neonatal mortality associated with $N$. caninum were reported in sheep and goats (Dubey, 2003; Dubey and Schares, 2011; Porto et al., 2016). The presence of canids and felids together with small ruminants in the pastures, pens, and barns act as potential epidemiological factors for these protozoa infections (Mainar et al., 1996; Ferreira et al., 2016; Udonsom et al., 2020).

In Egypt, small ruminants represent the second major source of red meat for consumers and lambs and kids are fattened for special religious and social occasions (Ministry of Agriculture and Land Reclamation in Egypt; FAO, 2003). In 2019, Egypt owned about 5.13 and 3.46 million heads of sheep and goats respectively, based on the FAOSTAT database (www.fao.org/faostat/en/\#data/QA). Animals are raised under an extensive system, in which animals are reared in herds/flocks and kept grazing natural pastures or raised under an intensive farming system for production of fattened lambs/kids or reared under semi-intensive farms (Ministry of Agriculture and Land Reclamation in Egypt; FAO, 2003; Galal, 2007). In the former semi-intensive farming system, small ruminants (sheep and/or goats) are reared with large ruminants (cattle and/or buffalo) together with domestic poultry (FAO, 2017). This is the most common system for the traditional Egyptian small-scale farmers and is widely scattered throughout the country. Usually, in these small farms in the farmers' houses animals are contacted with dogs and cats resulting in a high risk for occurrence of toxoplasmosis and/or neosporosis between individual animals in that farm.

For the development of an effective control strategy for toxoplasmosis and neosporosis, serological screening and knowledge on risk factors for infection are required (Dubey and Schares, 2011; Guido et al., 2016; Stelzer et al., 2019). Numerous serological evaluations include the indirect fluorescent antibody test (IFAT), enzyme-linked immunosorbent assay (ELISA), modified agglutination test (MAT), latex agglutination test (LAT), and indirect hemagglutination (IHA) are commonly used for the serologic prevalence of toxoplasmosis in sheep (Dubey, 2009). Several serologic techniques can be used to identify $N$. caninum antibodies involving several ELISAs, the Neospora agglutination test (NAT) and the indirect fluorescent antibody test (IFAT) (Dubey, 2003). Currently, enzymelinked assays are used to diagnose toxoplasmosis, the most common of which is the enzyme-linked immunosorbent assay (ELISA) (Ferra et al., 2020). Moreover, ELISA represents the technique of choice for high-throughput screening for N. caninum infection (Guido et al., 2016).

Up to date regarding the southern regional area in Egypt, a little is known about the seroprevalence of toxoplasmosis among small ruminants. Furthermore, the occurrence of $N$. caninum infection among sheep and goats has not been recorded in such southern Egyptian governorates. Therefore, this work aimed to investigate the presence of $N$. caninum and T. gondii infections in abortive cases in small ruminants using the ELISA technique from different farms in the Luxor governorate.

\section{MATERIALS AND METHODS}

\section{FARMS AND ANIMALS}

A total number of 184 heads of small ruminants were investigated in this study during the period from January 2019 to January 2020. Sheep $(n=92)$ and goats $(n=92)$ were sampled from 25 farms located in four different districts namely, Al-Qurnah, Armant, At-Tod, and Esna in Luxor governorate in southern Egypt (Figure 1). These animals were aged from 1 over 3 years (mixed age) and included both sexes. The samples were obtained randomly from all the visited farms (smallholder and intensive farms) with a special recording of numbers of ewes and does that suffered from previous abortion. The detailed information of the various groups of tested animals according to their species, ages and sexes is shown in Table 1.

\section{BLOOD SAMPLING}

Blood samples were collected from sheep $(n=92)$ and goats $(n=92)$ for the serological investigations of $T$. gondii and $N$. caninum. About $5 \mathrm{ml}$ blood was collected via jugular venipuncture under aseptic conditions (Bassert and McCurnin, 2013), then transferred to plain vacutainer tubes and centrifuged for $15 \mathrm{~min}$ at $3000 \mathrm{rpm}$ at room temperature for separation of serum. Collected sera were stored at $-20^{\circ} \mathrm{C}$ until tested.

\section{DETECTION OF T. GONDII AND N. CANINIUM ANTIBODIES BY ELISA}

Sheep ( $n=92)$ and goats $(n=92)$ from different farms in Luxor were serologically investigated for infection by $T$. gondii or $N$. caninum or both protozoa via indirect ELISA assay, using commercial ELISA kits. All 184 serum samples were tested for the presence of anti- $T$. gondii antibodies and anti- $N$. caninum antibodies by using 
ID Screen Toxoplasmosis Indirect Multispecies kit (ID. vet, rue Louis Pasteur, Grabels- France) and ID Screen Neospora caninum Indirect kit (ID.vet, rue Louis Pasteur, Grabels- France), respectively. Steps for ELISA protocol were done according to the manufacturer's instructions. The optical density (OD) was measured at $450 \mathrm{~nm}$. The $\mathrm{S} / \mathrm{P}$ percentage of each sample was calculated as follows:

$$
\mathrm{S} / \mathrm{P}=\frac{O D \text { sample }-O D n c}{O D p c-O D n c} \times 100
$$

ODnc: mean OD value of negative control, ODpc: mean $\mathrm{OD}$ of positive control, and samples with an $\mathrm{S} / \mathrm{P}$ value $\geq$ $50 \%$ were considered positive.

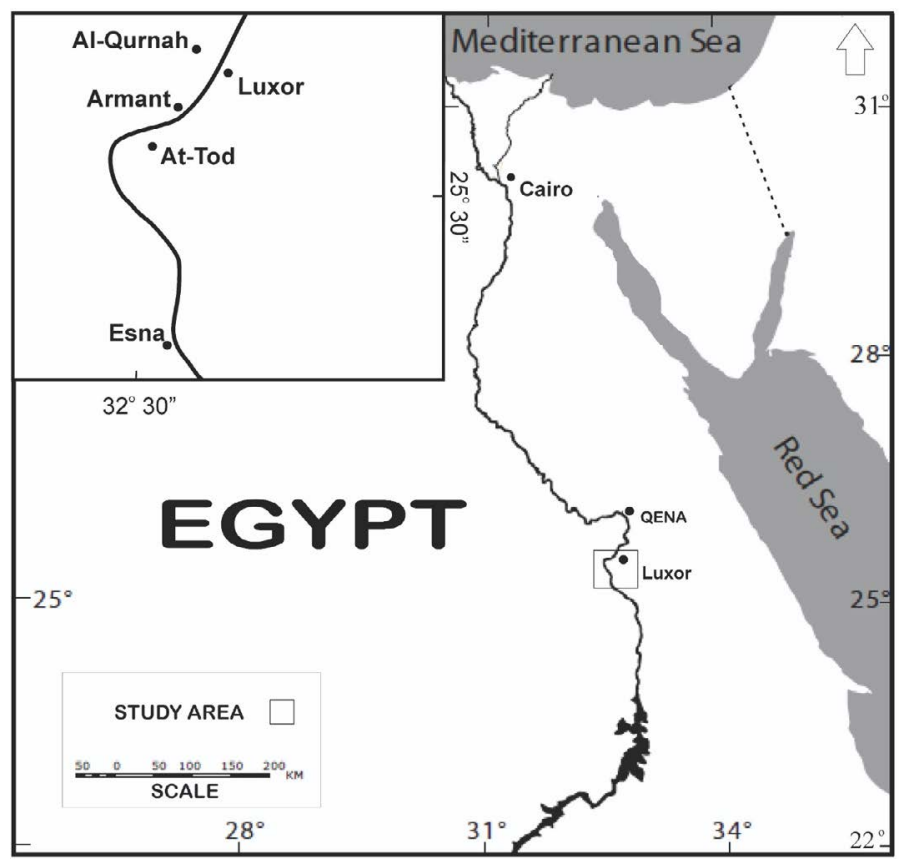

Figure 1: Map of Luxor, Egypt showing the geographic location of four different districts (A1-Qurnah, Armant, At-Tod, and Esna) visited for samples collection.

\section{StaTistical ANALYSIS}

The infection rates of toxoplasmosis and neosporosis among sheep and goats were determined by direct counting. The significance of the differences in the incidence rates of the different diseases and risk factors was determined with a chi-square $(\chi 2)$ test. A P value of $<0.05$ was considered statistically significant. Odds ratios and the $95 \%$ confidence intervals were calculated using www.vassarstats.net.

\section{RESULTS AND DISCUSSION}

Serum samples were collected from 184 animals (Sheep and goats), in four districts in the Luxor governorate (Table 1, Figure 1). Out of 92 heads of sheep investigated here, 37 (40.2\%) were positive for T. gondii infection. While the percentage of positivity for $N$. caninum infection was very low as we identified only $6(6.5 \%)$ positive cases from the examined ( 92 heads) sheep. From 92 goats examined here, 32 heads 32 (34.8\%) were seropositive for T. gondii. Surprisingly, all examined goats were tested negative for $N$. caninum infection (Table 2). The results showed that the highest infection rate of T. gondii for sheep was at Esna as 46.7\% while in At-Tod district the infection rate was 33.3\% and was the lowest one . Notably, the highest result of $N$. caninum antibody for sheep was at Al-Qurnah (9.4\%), the lowest result also recorded in At-Tod (3.7\%) (Table 2). In the case of goats, the highest seropositive result of $T$. gondii was at Armant 37\% while Al-Qurnah and Esna districts recorded the same low result as $33.3 \%$. All serum sampled from goats in the four districts showed (0) results against $N$. caninum antibodies (Table 2). In our investigations, samples were collected from both genders but limited numbers of rams and bucks were available from the visited farms. Indeed, two of the five rams tested positive for $T$. gondii antibodies and one showed a positive reaction for $N$. caninum antibodies, and two of the six bucks tested positive for toxoplasmosis.

Out of 87 ewes and 86 does 48 and 43 females had a history of abortion, respectively. The seroprevalence of $T$. gondii in aborted ewes was $62.5 \%$ (30 of 48). However, from 39 non-aborted ewes five cases (12.8\%) were seropositive for anti-T. gondii antibody (Table 3). Similarly, in aborted does $62.8 \%$ (27 of 43 ) were positive for $T$. gondii and only three females were tested positive from 43 non-aborted ones (Table 4). On the other hand, the infection rate of $N$. caninum in aborted ewes (8.3\%) was also higher than that in non-aborted females (2.6\%) (Table 5). While the aborted does were not suffering from $N$. caninum infection.

An epidemiological study was conducted as risk factors to establish the effect of age, sex, history of abortion and farming system (individual/smallholding and intensive farming system) on the prevalence of $T$. gondii infections in sheep. There were $37 \%$ (10 of 27) positive samples for the age group $<3$ years, $41.5 \%$ (27 of 65 ) for age group $>3$ years. The result obtained was subjected to a Chi-squared test. The result showed that seroprevalence of $T$. gondii antibody in various age groups was statistically non-significant ( $p$ value 0.68 ), odd ratio (OR) was (0. 82). Aborted ewes $62.5 \%$ compared with non-aborted ewes $12.8 \%$ (odd ratio $11.33, \mathrm{P}$ value $<0.0001)$. Other risk factors as sex and farming system were statistically non-significant (Table 3).

The effect of age, sex, history of abortion and farming system (individual/ smallholding and intensive farming system) on the prevalence of $T$. gondii infections in goats were evaluated. In contrast to sheep, the seroprevalence in goats was higher in young ( $<3$ years) $(45.5 \%)$ than in older ones (31.4\%). The result of aborted does and non-aborted were $62.8 \%$ and $7 \%$, respectively (OR 22.50, $\mathrm{P}$ value $<0.0001)$. Moreover, other risk factors comprising age, sex, 
Table 1: Localities, species, age and sex of tested animals.

\begin{tabular}{|c|c|c|c|c|c|c|}
\hline \multirow[t]{3}{*}{ Sample area } & \multirow[t]{3}{*}{ Farming system ${ }^{1}$} & \multicolumn{4}{|c|}{ Tested animals ${ }^{2}$} & \multirow{3}{*}{ Total } \\
\hline & & \multicolumn{2}{|l|}{ Sheep } & \multicolumn{2}{|c|}{ Goats } & \\
\hline & & Ewes $^{3}$ & Rams & Does $^{3}$ & Bucks & \\
\hline Al-Qurnah & Individuals/smallholders & 30 & 2 & 14 & 1 & 47 \\
\hline Armant & Individuals/smallholders & 17 & 1 & 26 & 1 & 45 \\
\hline At-Tod & Intensive farms & 25 & 2 & 32 & 3 & 62 \\
\hline Esna & Intensive farms & 15 & - & 14 & 1 & 30 \\
\hline Total & & 87 & 5 & 86 & 6 & 184 \\
\hline
\end{tabular}

${ }^{1}$ Farming system in the visited farms in Al-Qurnah, Armant, At-Tod, and Esna, comprised extensive farming system named as individual or smallholder in which animals reared in small groups (1-10 heads), and intensive farming system in which animals reared in large groups (50-hundred's heads). ${ }^{2}$ All tested animals groups in our approach aged from 1-3 years and over 3 years (mixed age). ${ }^{3}$ From all of the visited farms in A1-Qurnah, Armant, At-Tod, and Esna, some females (ewes and does) were suffering from previous abortion cases.

Table 2: Infection rates of Toxoplasmosis and Neosporosis in small ruminants in some Luxor farms as determined by ELISA.

\begin{tabular}{llllllll} 
Localities & Farms ID & \multicolumn{3}{c}{ Occurrence of Toxoplasmosis and Neosporosis } \\
& & \multicolumn{3}{c}{ Sheep } & No. tested & \multicolumn{2}{c}{ Go. positive (\%) } \\
& & No. tested & $\begin{array}{l}\text { No. positive (\%) } \\
\text { T.gondii }\end{array}$ & N. caninum & & T.gondii & N. caninum \\
Al-Qurnah & Q1-Q8 & 32 & $14(43.8)$ & $3(9.4)$ & 15 & $5(33.3)$ & $0(0.0)$ \\
Armant & A1-A4 & 18 & $7(38.9)$ & $1(5.6)$ & 27 & $10(37.0)$ & $0(0.0)$ \\
At-Tod & T1-T7 & 27 & $9(33.3)$ & $1(3.7)$ & 35 & $12(34.1)$ & $0(0.0)$ \\
Esna & E1-E6 & 15 & $7(46.7)$ & $1(6.7)$ & 15 & $5(33.3)$ & $0(0.0)$ \\
Total & 25 & 92 & $37(40.2)$ & $6(6.5)$ & 92 & $32(34.8)$ & $0(0.0)$
\end{tabular}

${ }^{1}$ In all of the visited farms in Al-Qurnah, Armant, At-Tod, and Esna, sheep and goats were reared together in one group.

Table 3: Risk factors associated with T. gondii infection among tested sheep.

\begin{tabular}{|c|c|c|c|c|}
\hline Analyzed risk factor & No. tested & No. positive (\%) & OR $(95 \% \mathrm{CI})^{1}$ & Pvalue $^{2}$ \\
\hline \multicolumn{5}{|l|}{ Age } \\
\hline$<3$ years & 27 & $10(37.0)$ & $0.82(0.32-2.08)$ & 0.68 \\
\hline$>3$ years & 65 & $27(41.5)$ & & \\
\hline \multicolumn{5}{|l|}{ Sex } \\
\hline Male & 5 & $2(40.0)$ & $0.99(0.15-6.23)$ & - \\
\hline Female & 87 & $35(40.2)$ & & \\
\hline \multicolumn{5}{|l|}{ History of abortion } \\
\hline Aborted ewes & 48 & $30(62.5)$ & $11.33(3.75-34.24)$ & $<0.0001$ \\
\hline Non-aborted ewes & 39 & $5(12.8)$ & & \\
\hline \multicolumn{5}{|l|}{ Farming system } \\
\hline Individuals/smallholders & 52 & $20(38.5)$ & $1.1(0.36-1.95)$ & 0.69 \\
\hline Intensive farms & 40 & $17(42.5)$ & & \\
\hline
\end{tabular}

and breeding system were statically non-significant (Table 4).

Risk factors associated with $N$. caninum infection among tested sheep. In the present study, no significant risk factors were recorded for N. caninum in sheep. Regarding to gender, there was a considerable correlation between ram and ewe $(20.0 \%, 5.7 \%)$ respectively (Table 5$)$. On own investigation in Luxor farms, reveal that the examined sheep can be infected with both toxoplasmosis and neosporosis diseases. Indeed, we identified a mixed infection for both pathogens in 4 individuals ( 3 ewes and $1 \mathrm{ram}$ ) among examined sheep. Interestingly, two of the females had a previous history of abortion (Table 6). 
Table 4: Risk factors associated with T. gondii infection among tested goats.

\begin{tabular}{|c|c|c|c|c|}
\hline Analyzed risk factor & No. tested & No. positive (\%) & OR $(95 \% \mathrm{CI})^{1}$ & $\mathbf{P}$-value ${ }^{2}$ \\
\hline \multicolumn{5}{|l|}{ Age } \\
\hline$<3$ years & 22 & $10(45.5)$ & $1.81(0.68-4.84)$ & 0.22 \\
\hline$>3$ years & 70 & $22(31.4)$ & & \\
\hline \multicolumn{5}{|l|}{ Sex } \\
\hline Male & 6 & $2(33.3)$ & $0.93(0.16-5.39)$ & - \\
\hline Female & 86 & $30(34.9)$ & & \\
\hline \multicolumn{5}{|l|}{ History of abortion } \\
\hline Aborted does & 43 & $27(62.8)$ & $22.50(5.97-84.75)$ & $<0.0001$ \\
\hline Non-aborted does & 43 & $3(7 \%)$ & & \\
\hline \multicolumn{5}{|l|}{ Farming system } \\
\hline Individuals/smallholders & 42 & $15(35.7)$ & $1.07(0.45-2.55)$ & 0.86 \\
\hline Intensive farms & 50 & $17(34.0)$ & & \\
\hline
\end{tabular}

Table 5: Risk factors associated with $N$. caninum infection among tested sheep.

\begin{tabular}{|c|c|c|c|c|}
\hline Analyzed risk factor & No. tested & No. positive (\%) & OR $(95 \% \mathrm{CI})^{1}$ & P-value ${ }^{2}$ \\
\hline \multicolumn{5}{|l|}{ Age } \\
\hline$<3$ years & 27 & $2(7.4)$ & $1.22(0.20-7.09)$ & - \\
\hline$>3$ years & 65 & $4(6.2)$ & & \\
\hline \multicolumn{5}{|l|}{ Sex } \\
\hline Male & 5 & $1(20)$ & $4.1(0.38-43.86)$ & - \\
\hline Female & 87 & $5(5.7)$ & & \\
\hline \multicolumn{5}{|l|}{ History of abortion } \\
\hline Aborted ewes & 48 & $4(8.3)$ & $3.45(0.37-32.25)$ & - \\
\hline Non-aborted ewes & 39 & $1(2.6)$ & & \\
\hline \multicolumn{5}{|l|}{ Farming system } \\
\hline Individuals/smallholders & 52 & $4(7.7)$ & $1.58(0.27-9.11)$ & - \\
\hline Intensive farms & 40 & $2(5.0)$ & & \\
\hline
\end{tabular}

Table 6: Mixed infection with both T. gondii and N. caninum among tested sheep.

$\begin{array}{lllll}\text { Tested sheep } & \text { No.tested } & \text { No. mixed infected (\%) } & \text { Age } & \text { Region } \\ \text { Ram } & 5 & 1(20.0) & <3 \text { years } & \text { Al-Qurnah } \\ \text { Aborted ewes } & 48 & 2(4.2) & >3 \text { years } & \text { Al-Qurnah- } \text { Armant }^{\mathrm{a}}(1 \text { head each region) } \\ \text { Non-aborted ewes } & 39 & 1(2.6) & <3 \text { years } & \text { At-Tod } \\ \text { Total } & 92 & 4(4.3) & & \end{array}$

${ }^{a}$ Infected cases from the tested farms at A1-Qurnah and Armant were kept in groups with dogs (livestock guardian dogs) and some stray cats.

Sheep and goats are widely distributed and consider the main components of the agricultural sector in Egypt. Moreover, they are the main sources of animal protein and play a critical role in maintaining the food supplies and economic security of Egypt and developing countries. To date, few studies have investigated the serological prevalence of $T$. gondii and $N$. caninum infections among sheep and goats in southern Egypt and this is the first study in Luxor governorate. We demonstrated a higher infection rate of toxoplasmosis than that of neosporosis. $T$. gondii considers the primary parasite responsible for both sheep and goat abortion. However, the economic, clinical, 
and epidemiological importance of $N$. caninum infection in mentioned species remains uncertain (Dubey and Schares, 2011).

In the present study, the seroprevalence of $T$. gondii in sheep and goats was $40.2 \%$ and $34.8 \%$ by using ELISA, respectively. We compared our results with previous studies for the seroprevalence of $T$. gondii infection in the neighbor regions and some other governorates in Egypt. In the closer area, our previous report in Qena governorate showed the infection rates of toxoplasmosis in sheep and goats as $56.8 \%$ and $48.2 \%$ using ELISA respectively (Fereig et al., 2016a). These results were close to or little higher than that reported in this study. However, in Assiut governorate, the seroprevalence of $T$. gondii was $86.0 \%$ among tested sheep that was higher than we identified and $87.7 \%$ in goats that was a markedly higher prevalence than we recorded (Kuraa and Malek, 2016). In Al-fayium governorate, the seroprevalence of toxoplasmosis in sheep (98.4\%) was extremely higher than that we identified here and $41.7 \%$ in goats, which also was being higher than that we recorded (Ghoneim et al., 2010). In Dakahlia governorate, $62.0 \%$ from tested sheep and 50.6\% from tested goat were seropositive for $T$. gondii by using ELISA (Younis et al., 2015). In Cairo, the seroprevalence of $T$. gondii in sheep was $61.4 \%$ using ELISA (Hassanain et al., 2011) and these results were considered higher than that we investigated.

Observing the prevalence in sheep, $40.2 \%$ seropositive, the prevalence rate among screened animals in our study, was higher than that recorded in Sharkia governorate, as 18\% using IHAT method (Awadallah, 2010). Moreover, low results were observed in Cairo, Dakahlia, Sharkia, and Giza governorates, with 12.0\%, 27.0\%, 17.1\%, and 26.2 $\%$ infection rates, respectively (Al-Kappany et al., 2018). Furthermore, using ELISA, 34.0\% was demonstrated as seroprevalence of T. gondii in sheep in Ismailia governorate (El-Gawady et al., 2018). In the present study, the seroprevalence of $T$. gondii in goats was $34.8 \%$ by ELISA. Our results were relatively higher than those reported in different areas in Egypt 28.1\% at Cairo by ELISA (Abd El-Razik et al., 2018; Abbas et al., 2019), and 32.0\% (E1Gawady et al., 2018). Our result was lower than another finding in Egypt as in Dakahlia 50.6\% (Younis et al., 2015), 59.0\% and 54.0\% (A1-Kappany et al., 2018) by using ELISA and IFA, respectively and $43.0 \%$ documented at Cairo, Giza, Kalubyia using ELISA (El-Fadaly et al., 2017). Moreover 36.3\%, 53.6\% were recorded from Giza and Sharkia, respectively by using ELISA (Abd El-Razik et al., 2018). Such differences in the prevalence of toxoplasmosis may be attributed to breeding condition, immune status, the timing of infection, the genetic composition of the host and the organism (Suzuki, 2002; Masala et al., 2003) and diagnostic techniques, the ELISA test considers the more suitable test in the diagnosis of toxoplasmosis in ruminants (Younis et al., 2015). Our results revealed that the $T$. gondii parasite is widely spread due to they tend to wander more freely in the urban area of Egypt than other ruminants and thus have direct contact with domestic cat faeces (Abdel-Rahman et al., 2012). The higher prevalence rates of toxoplasmosis in ruminants in our study due to a warm and moist environment leads to long viability of $T$. gondii oocysts in environments and the presence of a stray cat in our rural areas which increase contamination of the environment with shedding oocysts.

Our result showed that $62.5 \%$ from aborted ewes were ELISA positive for $T$. gondii which is higher than that previously reported results $(53.3 \%, 40.0 \%)$ as estimated by LAT and PCR methods, respectively (Khater et al., 2013) and $31.0 \%$ by IHA (Mahboub et al., 2013). Regarding to gender in the present study, the infection rate by ELISA was $40.2 \%$ in ewes and $40.0 \%$ in rams which has no statistically significant difference between infection rate and gender. Other studies revealed a higher prevalence of $T$. gondii in females than in males that conducted in northern Egypt (Selim et al., 2021). Moreover, many reports did not show a significant correlation between males and females similar to our findings (Kamani et al., 2010; Khamesipour et al., 2014). The seroprevalence of $T$. gondii was higher in does (34.9\%) than in bucks (33.3\%) which has no statistically significant difference, similar results reported by ( $\mathrm{Xu}$ et al., 2014). Regarding to aborted does in the present study, the seroprevalence of T. gondii was $62.8 \%$ higher than $35.4 \%$ and $22.9 \%$ by using IHA-IgG and MAT-IgM, respectively (Ramadan et al., 2007) and 17.1\%by IHA-IgM (Mahboub et al., 2013). Furthermore, our study was lower than other reported in aborted does $80.0 \%$ by using DAT (Attia et al., 2017).

$N$. caninum was first discovered and described in 1988, and since then it was reported in many animal species worldwide (Li et al., 2015). In the current study, the seroprevalence of $N$. caninium in sheep was $6.5 \%$ by using ELISA, while in goats not recorded. Our results reveal that Neospora caninum is present in sheep more than in goat, similar to previous studies (Liu et al., 2015). Not a lot of research has been done on neosporosis in small ruminants in Egypt, only one research performed in sheep in northern Egypt (Selim et al., 2021) showed 8.6\% using ELISA which is higher than our result. To our knowledge, there is no data available for prevalence of $N$. caninium in goats in Egypt. Hence our study considers the first research in the southern region of Egypt. On the other hand, there are some research studies on neosporosis in other species reported $85 \%, 20.43 \%$ and $7.92 \%$ seroprevalence in humans, cattle and rabbits, respectively using ELISA methods based on surface antigen 1 of $N$. caninum (Nc SAG1t) (Ibrahim et al., 2009). Furthermore 18.9\% was detected in cattle by 
ELISA (Fereig et al., 2016b). On own survey in Luxor farms, reveal that about $4.3 \%$ of total examined sheep were infected with both $N$. caninum and T. gondii (mixed infection). Our results were relatively higher than those reported in sheep 3.2\% (Gharekhani et al., 2018), 1.35\% (Moreno et al., 2012). Our records were lower than those recorded previously in sheep as 20\% (Rossi et al., 2011). During samples collection from different farms in Luxor only a limited number from males was available. It was interesting that, only one ram from tested five individuals was positive reactor for both pathogens. From six bucks tested here, two were positive reactors for toxoplasmosis but no positive reactors were identified for neosporosis. Our findings provided the first evidence of T. gondii and $N$. caninum infections in sheep and goats flocks in the districts and villages of Luxor governorate and provided some epidemiological data for the occurrence of such cosmopolitan protozoa among small ruminants.

T. gondii and N. caninum consider zoonotic diseases as they introduce infective oocysts to the environment. Humans obtained toxoplasmosis via the eating of undercooked meat and mutton (Dubey and Jones, 2008). Infection with T. gondii in humans looked like flu fatigue, while immune depressed patients especially (AIDs patients) are most vulnerable to infection complicated to headache, encephalitis, convulsions, drowsiness and blindness. Females infected with $T$. gondii during pregnancy develop spontaneous abortion or give child suffer from hydrocephalus, mental retardation, blindness and deafness (Zewdu et al., 2013; Dubey and Beattie, 1988). Previous research in Egypt has evaluated the seroprevalence of $T$. gondii in humans, found that $2.9 \%$ in children (Bayoumy et al., 2016). In the case of pregnant women in contact with cats $20.4 \%$ (Hassanain et al., 2018), $47.1 \%$ by Hussein et al. (2017). Moreover, Abdelbaset et al. (2020) found 30.2\% in pregnant women. $N$. caninum causes abortion and encephalitis in many animals like cattle, sheep and goats so it is misdiagnosed with T. gondii. Recently, the zoonotic effect of that parasite in humans considers opportunistic as the estimation of $N$. caninum antibodies in human tissues reveal low titer and the infection not proved (Dubey et al., 2007; Calero et al., 2019). There is little published data investigate the presence of anti- $N$. caninum antibody in Egypt detected 1.85\%in humans using ELISA methods based on surface antigen 1 of $N$. caninum (Nc SAG1t) (Ibrahim et al., 2009). Based on the recommendation of the Centers for Disease Control and Prevention, U.S.A. (https://www.cdc.gov/parasites/toxoplasmosis/prevent. html) to avoid such zoonotic diseases, individuals should follow these three main precautions: reduce risk from food (thoroughly cook foods and washing well of fruits), reduce risk from the environment and avoid direct contact with the cat in pregnant women or immunocompromised individuals.

\section{CONCLUSIONS AND RECOMMENDATIONS}

The results of this study provide new insights into the occurrence of toxoplasmosis and neosporosis in small ruminants in the Luxor governorate. The seroprevalence rates of $T$. gondii infections observed in sheep and goats in this study were relatively high and the incidence $N$. caninum infection was recorded in sheep. This may indicate an important role of goat and sheep in the transmission of human toxoplasmosis and neosporosis in Egypt, given the habit of eating undercooked grilled mutton. More studies are needed to understand the high rates of these parasitic infections in Egypt. This requires the application of more effective strategies for resisting these types of infections on farms in Egypt.

\section{ACKNOWLEDGMENTS}

The authors would like to thank Montasar Abas Boghdady a Chemist in a Holding Company for Water and Sanitation in Luxor for his support and cooperation in obtaining some analytic materials.

\section{NOVELTY STATEMENT}

This research is considered a key survey to understand the distributions of toxoplasmosis and neosporosis in small ruminants in Luxor, Egypt.

\section{AUTHOR'S CONTRIBUTION}

Ali AO and Mahmoud HYAH designed the study. Aboelwafa SS collected the samples. Aboelwafa SS, Mahmoud HYAH and Ali AO made the experiments and revised the manuscript. Hamada $\mathrm{R}$ wrote some parts of the manuscript and performed the statistical analysis. Aboelwafa SS and Hamada R analyzed the data. All authors revised and approved the final manuscript.

\section{CONFLICT OF INTEREST}

The authors have declared no conflict of interest.

\section{REFERENCES}

Abbas IE, Villena I, Dubey JP (2019). A review on toxoplasmosis in humans and animals from Egypt. Parasitology, pp. 1-25. https://doi.org/10.1017/S0031182019001367

Abd El-Razik KA, Barakat AMA, Hussein HA, Younes AM, Elfadaly HA, Eldebaky HA, Soliman YA (2018). Seroprevalence, isolation, molecular detection and genetic diversity of Toxoplasma gondii from small ruminants. J. Egypt. Soc. Parasitol., 42(4): 527-536. https://doi.org/10.1007/ s12639-018-1029-4

Abdelbaset AE, Hamed MI, Abushahba MFN, Rawy MS, Sayed 
ASM, Adamovicz JJ (2020). Toxoplasma gondii seropositivity and the associated risk factors in sheep and pregnant women in El-Minya Governorate, Egypt. Vet. World, 13(1): 54-60. https://doi.org/10.14202/vetworld.2020.54-60

Abdel-Rahman MA, EL-Manyawe SM, Khateib AM, Saba S (2012). Occurrence of toxoplasma antibodies in caprine milk and serum in Egypt. Assiut Vet. Med.J., 133: 145- 152.

Al-Kappany YM, Abbas IE, Devleesschauwer B, Dorny P, Jennes M, Cox E (2018). Seroprevalence of anti-Toxoplasma gondii antibodies in Egyptian sheep and goats. BMC Vet. Res., 14: 120. https://doi.org/10.1186/s12917-018-1440-1

Attia MM, Saad MF, Abdel-Salam AB (2017). Milk as a substitute for serum in diagnosis of toxoplasmosis in goats. J. Egypt. Soc. Parasitol., 47(1): 227-234. https://doi. org/10.21608/jesp.2017.78039

Awadallah MAI (2010). Endoparasites of zoonotic importance. Glob. Vet. 5(6): 348- 355.

Bassert JM,McCurnin DM (2013).McCurnin's clinical textbook for veterinary technicians. Elsevier Health Sci. J., 10: 120128.

Bayoumy AMS, Ibrahim WLF, Abou El Nour BM, Said AAA (2016). The parasitic profile among school children in E1wadi El-gadded governorate, Egypt.J. Egypt. Soc. Parasitol., 46(3): 605-612. https://doi.org/10.21608/jesp.2016.88265

Calero-Bernal R, Horcajo P, Hernández M, Ortega-Mora L, Fuentes I (2019). Absence of Neospora caninum DNA in human clinical samples, Spain. Emerg. Infect. Dis., 25(6): 1226-1227. https://doi.org/10.3201/eid2506.181431

De Barros LD, Garcia JL, Bresciani KDS, Cardim ST, Storte VS, Headley SA (2020). A review of toxoplasmosis and neosporosis in water buffalo (Bubalus bubalis). Front. Vet. Sci., 7: 455. https://doi.org/10.3389/fvets.2020.00455

Dubey J, Beattie C (1988). Toxoplasmosis of animals and man oocysts in non-pregnant sheep and the effects of subsequent challenge during pregnancy CRC Press, Boca Raton, Florida, USA. Vet. Rec., 123: 467-470. https://doi. org/10.1136/vr.123.18.467

Dubey JP (1996). Toxoplasma gondii. In: Baron S, editor. Medical Microbiology. $4^{\text {th }}$ edition Galveston (TX): University of Texas Medical Branch at Galveston: Chapter 84. Available from: https://www.ncbi.nlm.nih.gov/books/NBK7752

Dubey JP (2009). Toxoplasmosis in sheep the last 20 years. Vet. Parasitol., 163(1-2): 1-14. https://doi.org/10.1016/j. vetpar.2009.02.026

Dubey JP (2003). Review of Neospora caninum and neosporosis in animals. Korean J. Parasitol., 41(1):1-16. https://doi. org/10.3347/kjp.2003.41.1.1

Dubey JP, Jones JL (2008). Toxoplasma gondii infection in humans and animals in the United States. Int. J. Parasitol., 38: 12571278. https://doi.org/10.1016/j.ijpara.2008.03.007

Dubey JP, Schares G (2011). Neosporosis in animals the last five years. Vet. Parasitol., 180 (1-2): 90-108. https://doi. org/10.1016/j.vetpar.2011.05.031

Dubey JP, Schares G, Ortega-Mora LM (2007). Epidemiology and control of neosporosis and Neospora caninum. Clin. Microbiol. Rev.,. 20: 323-367. https://doi.org/10.1128/ CMR.00031-06

El-Fadaly HA, Hassanain NA, Shaapan RM, Hassanain MA, Barakat AM, Abdelrahman KA (2017). Molecular detection and genotyping of Toxoplasma gondii from Egyptian isolates. Asian J. Epidemiol., 10(1): 37-44. https://doi.org/10.3923/ aje.2017.37.44

El-Gawady HM, Abdel-Aal AA, Sallam NH, Youissif EM
(2018). Serological and molecular studies on Toxoplasma gondii infection in sheep and goats in Ismailia Province. Arch. Infect Dis. Ther., 2: 1-5. https://doi.org/10.33140/ AIDT/02/02/00004

FAO (2017). Study on small-scale agriculture in the Near East and North Africa region (NENA) Focus Country: Egypt. Rome, available at http://www.fao. org/3/i6497e/i6497e.

FAOSTAT (2019). FAO Statics Division.

Fereig-Ragab M, Hassan MYAH, Samy MGA, Mahmoud R, Abdel-wahab A, Salama A, Sherif A, El-khodary SA, Elsayed AMA, Yoshifumi N (2016a). Seroprevalence and epidemiology of Toxoplasma gondii in farm animals in different regions of Egypt. Vet. Parasitol. Reg. Stud. Rep., 3: 1-6. https://doi.org/10.1016/j.vprsr.2016.05.002

Fereig Ragab M, Rezk M, Mohamed SGA, Mahmoud HYAH, Ali AO, Ali AF, Hilali M,Zaid A, Elsayed AMA, Nishikawa Y (2016b). Serological detection and epidemiology of Neospora caninum and Cryptosporidium parvum antibodies in cattle in southern Egypt. Acta Trop., 162: 206211. https://doi.org/10.1016/j.actatropica.2016.06.032

Ferra B, Holec-Gąsior L, Grąźlewska W (2020). Toxoplasma gondii recombinant antigens in the serodiagnosis of toxoplasmosis in domestic and farm animals. Animals (Basel), 10(8): 1245. https://doi.org/10.3390/ani10081245

Ferreira MST, Vogel FSF, Sangioni LA, Cezar AS, de Menezes FR (2016). Neospora spp. and Toxoplasma gondii infection in sheep flocks from Rio Grande do Sul, Brazil. Semina: Ciênc. Agrár., 37(3): 1397-1406. http://www.redalyc.org/ articulo.oa?id=445746397025 https://doi.org/10.7458/ SPP2011677761

Galal S (2007). Farm animal genetic resources in Egypt: factsheet. Egypt J. Anim. Prod., 44(1): 1-23. https://doi. org/10.21608/ejap.2007.93148

Gharekhani J, Yakhchali 1M, Esmaeilnejad B, Mardani K, Majidi G, Sohrabi A, Berahmat R, Hazhir-Alaei M (2018). Seroprevalence and risk factors of neospora caninum and Toxoplasma gondii in small ruminants in Southwest of Iran. Arch. Razi Inst., 73(4): 305-310.

Ghoneim NH, Shalaby SI, Hassanain NA, Zeedan GS, Soliman YA, Abdalhamed AM (2010). Comparative study between serological and molecular methods for diagnosis of toxoplasmosis in women and small ruminants in Egypt. Foodborne Pathog. Dis., 7(1): 17-22. https://doi. org/10.1089/fpd.2008.0223

Guido S, Katzer F, Nanjiani I, Milne E, Innes EA (2016). Serology-based diagnostics for the control of bovine neosporosis. Trends Parasitol., 32(2): 131-143. https://doi. org/10.1016/j.pt.2015.11.014

Hassanain MA, Elfadaly HA, Abd El Wahab WM, Abo El-Maaty AM (2018). Comparative hormonal and immunoglobulin profiles of aborted women with or without toxoplasmosis. J. Pregnancy Reprod., 2(1): 1-4. https://doi. org/10.15761/JPR.1000130

Hassanain MA, Elfadaly HA, Shaapan RM, Hassanain NA, Barakat AM (2011). Biological assay of Toxoplasma gondii Egyptian mutton isolates. Int. J. Zool. Res., 7(4): 330-337. https://doi.org/10.3923/ijzr.2011.330.337

Hill DE, Chirukandoth S, Dubey JP (2005). Biology and epidemiology of Toxoplasma gondii in man and animals. Anim. Health Res. Rev., 6: 41-61. https://doi.org/10.1079/ AHR2005100

Hussein SMM, Elshemy AS, Abd El-Mawgod MM, 
Mohammed AS (2017). Seroprevalence of Toxoplasma gondii among primigravida women and their neonates in Sohag governorate, Egypt. J. Egypt Soc. Parasitol., 47: 381388. https://doi.org/10.21608/jesp.2017.77791

Ibrahim HM, Huang P, Salem TA, Talaat RM, Nasr MI, Xuan X, Nishikawa Y (2009). Short report: Prevalence of Neospora caninum and Toxoplasma gondii antibodies in northern Egypt. Am. J. Trop. Med. Hyg., 80: 263-267. https://doi. org/10.4269/ajtmh.2009.80.263

Kamani J, Mani AU, Egwu GO (2010). Seroprevalence of Toxoplasma gondii infection in domestic sheep and goats in Borno State, Nigeria. Ann. Trop. Med. Public Health, 2: 793-797. https://doi.org/10.1007/s11250-009-9488-3

Khamesipour F, Doosti A, Mobarakeh HI, Komba EVG (2014). Toxoplasma gondii in Cattle, Camels and Sheep in Isfahan and Chaharmahal va Bakhtiary Provinces, Iran. Jundishapur J. Microbiol., 7(6): e17460. https://doi.org/10.5812/ jjm.17460

Khater H F, Khalifa NO, Barakat, AMA (2013). Serological and molecular studies of ovine and human Toxo- plasmosis with a trial of treatment of infected ewes. Sci. J. Vet. Adv., 2(11): 157-168.

Kuraa HM, Malek SS (2016). Seroprevalence of Toxoplasma gondii in ruminants by using latex agglutination test (LAT) and enzyme-linked immunosorbent assay (ELISA) in Assiut governorate. Trop. Biomed., 33(4): 711-725.

Li K, Han ZQ, Shahzad M, Li JK (2015). Seroepidemiology of Neospora caninum infection in yaks (Bos grunniens) in Tibet and Hongyuan of Sichuan, China. Cattle Pract., 23: 142-143.

Liu Zi Kui, Li Jian Yong, Pan Hu (2015). Seroprevalence and risk factors of Toxoplasma gondii and Neospora caninum infections in small ruminants in China. Prev. Vet. Med., 118: 488-492. https://doi.org/10.1016/j.prevetmed.2014.12.017

Mahboub HD, Helal MA, Abd Eldaim MA, Abd El-Razek EM, Elsify AM (2013). Seroprevalence of abortion causing agents in Egyptian sheep and goat breeds and their effects on the animal's performance 4. J. Agric. Sci., 5(9): 92-101. https://doi.org/10.5539/jas.v5n9p92

Mainar RC, de la Cruz C, Asensio A, Domínguez L, VázquezBoland JA (1996). Prevalence of agglutinating antibodies to Toxoplasma gondii in small ruminants of the Madrid region, Spain, and identification of factors influencing seropositivity by multivariate analysis. Vet. Res. Commun., 20(2): 153-159. https://doi.org/10.1007/BF00385636

Masala G, Porcu R, Madau L, Tanda A, Ibba B, Satta G, Tola S (2003). Survey of ovine and caprine toxoplasmosis by IFAT and PCR assay in Sardina, Italy. Vet. Parasitol., 117: 15-21. https://doi.org/10.1016/j.vetpar.2003.07.012

Ministry of Agriculture and Land Reclamation in Egypt and FAO (2003). First report on the state of animal genetic resources in the Arab Republic of Egypt. FAO, Rome.

Moreno B, Collantes-Fernándezb E, Villa A, Navarro A, Regidor-Cerrillob J, Ortega-Mora LM (2012). Occurrence of Neospora caninum and Toxoplasma gondii infections in ovine and caprine abortions. Vet. Parasitol., 187(2): 312-
318. https://doi.org/10.1016/j.vetpar.2011.12.034

Porto WJ, Regidor-Cerrillo J, Kim Pde C, Benavides J, Silva AC, Horcajo P, Oliveira AA, Ferre I, Mota RA, Ortega-Mora LM (2016). Experimental caprine neosporosis: The influence of gestational stage on the outcome of infection. Vet. Res., 47: 29. https://doi.org/10.1186/s13567-016-0312-6

Ramadan MY, Abdel-Mageed AD, Khater HF (2007). Seroprevalence and preliminary treatment of toxoplasmosis of pregnant goats in Kalubyia Governorate, Egypt. Acta Sci. Vet., 35(3): 295-301. https://doi.org/10.22456/16799216.16119

Rossi GF, Cabral DD, Ribeiro DP, Pajuaba ACAM, Corrêa RR, Moreira RQ, Mineo TWP, Mineo JR, Silva DAO (2011). Evaluation of Toxoplasma gondii and Neospora caninum infections in sheep from Uberlândia, Minas Gerais State, Brazil, by different serological methods G.F. Vet. Parasitol., 175(3-4): 252-259. https://doi.org/10.1016/j. vetpar.2010.10.017

Sánchez-Sánchez R, Vázquez P, Ferre I, Ortega-Mora LM (2018). Treatment of Toxoplasmosis and Neosporosis in Farm Ruminants: State of Knowledge and Future Trends. Curr. Top. Med. Chem., 18(15): 1304-1323. https://doi.org/ 10.2174/1568026618666181002113617

Selim A, Khater H, Almohammed HI (2021). A recent update about seroprevalence of ovine neosporosis in Northern Egypt and its associated risk factors. Sci. Rep., pp. 1-6. https://doi.org/10.1038/s41598-021-93596-9

Stelzer S, Basso W, Benavides SJ, Ortega-Mora LM, Maksimov P, Gethmann J, Conraths FJ, Schares G (2019). Toxoplasma gondii infection and toxoplasmosis in farm animals: Risk factors and economic impact. Food Waterborne Parasitol., 15: e00037. https://doi.org/10.1016/j.fawpar.2019.e00037

Suzuki Y (2002). Host resistance in the brain against Toxoplasma gondii. J. Infect. Dis., 185: 58-65. https://doi. org/10.1086/337999

Udonsom R, Supanta J, Tanglakmankhong O, Ngoenphisutsin K, Nishikawa Y, Fereig RM, Jirapattharasate C (2020). Toxoplasma gondii and Neospora caninum prevalence and risk factors on goat farms in Kanchanaburi province, Thailand. Vet. Integr. Sci., 19(1): 65-74. https://doi.org/10.12982/ VIS.2021.006

Xu P, Li X, Guo L, Li B, Wang J, Yu D, Zhao Q, Liu X (2014). Seroprevalence of Toxoplasma gondii infection in Liaoning cashmere goat from north-eastern China. Parasite, 21: 22. https://doi.org/10.1051/parasite/2014023

Younis EE, Abou-Zeid NZ, Zakaria M, Mahmoud MR (2015). Epidemiological studies on toxoplasmosis in small ruminants and equines in Dakahlia governorate, Egypt. Assiut Vet. Med. J., 61: 22-31. https://doi.org/10.21608/ avmj.2015.169756

Zewdu EG, Hailu A, Tessema TS, Desta KT, Medhin G, Vitale M, Di Marco V, Cox E, Dorny P (2013). Seroepidemiology of Toxoplasma gondii infection in women of child- bearing age in central Ethiopia. BMC Infect. Dis., 13: 101. https:// doi.org/10.1186/1471-2334-13-101 